\title{
Occupational asthma in a hairdressing salon
}

\author{
AD BLAINEY, S OLLIER, D CUNDELL, RE SMITH, RJ DAVIES \\ From the Academic Unit of Respiratory Medicine and the Department of Medical Electronics, \\ St Bartholomew's Hospital, London
}

ABSTRACT Occupational asthma among hairdressers has been recognised for some years and cases of work related asthma due to hair bleaches containing persulphates and hair dyes have been reported. The extent of the disease among hairdressers remains unknown. An investigation was carried out on an entire hairdressing salon, which specialised in hair bleaching and colouring and which employed 23 staff. On the basis of history and specific and non-specific bronchial provocation testing, four out of 23 staff were found to have occupational asthma due to the persulphate salts contained in hair bleaches. Only one of these had a positive skinprick test response to persulphate salts. Tests for non-specific bronchial reactivity to histamine in this work force were more sensitive for the diagnosis of asthma than simple lung function tests or recordings of peak flow rates performed four times daily for three weeks. The response to these agents was studied in greater detail by specific bronchial provocation tests in 14 members of the salon as well as one hairdresser from elsewhere with occupational asthma, three individuals with non-occupational asthma, and four normal subjects. Only those with a history of work related asthma and bronchial hyperreactivity responded positively, confirming that the response to bleach powders was specific. Studies of pulmonary mechanics after challenge showed that the response arose from changes in airway calibre not lung volumes. Measurement of neutrophil chemotactic activity after challenge showed significant rises in those affected, suggesting that mast cells may play a part in the pathogenesis of occupational asthma due to persulphates.

Hairdressers may be exposed to various chemicals capable of producing respiratory symptoms and disease. Some are known to have irritant properties and acute respiratory reactions have been described after exposure to hair sprays, ${ }^{1}$ but others can produce asthma. Persulphate salts, which are widely used as constituents of hair bleaches, have been shown to cause asthma in hairdressers ${ }^{2-4}$ and chemical workers ${ }^{5}$; henna ${ }^{6}$ and other hair dyes containing paraphenylenediamine ${ }^{7}$ are also thought to be capable of producing asthma in some individuals. Little is known about the prevalence of asthma due to these agents or the mechanisms underlying asthma caused by these highly reactive, low molecular weight chemicals.

We report the results of an investigation conducted in a hairdressing salon that specialised in bleaching and colouring hair, in which the employees were frequently exposed to high concentrations of bleaching

Address for correspondence: $\operatorname{Dr} \mathrm{RJ}$ Davies, Department of Respiratory Medicine, St Bartholomew's Hospital, London EC1A 7BE.

Accepted 23 July 1985 agents, particularly persulphate salts. We have attempted to estimate the nature and prevalence of work related respiratory disease in this work force by interviews, lung function tests, and specific and nonspecific bronchial provocation tests. In these and other subjects we have studied the mechanisms and pathogenesis of asthma due to persulphate salts.

\section{Subjects and methods}

\section{SUBJECTS}

At the time of the survey the salon employed 23 staff, $\widetilde{N}$ all of whom agreed to participate. They included $12 \mathrm{~N}$ tinters, who specialised in bleaching and colouring $\mathcal{N}^{\circ}$ hair, and 11 stylists, who did not themselves use $\omega$ bleaches or dyes. Details of these subjects are given in tables 1 and 2 .

The tinters are the group most heavily exposed to bleaches and dyes. These chemicals are supplied to the ${ }^{+}$ salon in powder form and mixed with hydrogen per- $\frac{T}{0}$ oxide to form a paste, which is then applied to the hair $\stackrel{0}{\mathbb{D}}$ of the client. A fine dust is generated during the mixing $\frac{\mathrm{O}}{\mathbb{D}}$ of these compounds, which is readily inhaled. Venti- $\stackrel{\mathbb{Q}}{\Omega}$ lation appeared adequate in the salon, but in the sep-? 
Table 1 Details of employees of a hairdressing salon

\begin{tabular}{llll}
\hline & Tinters & Stylists & All \\
\hline $\begin{array}{l}\text { Number } \\
\text { Age (y) }\end{array}$ & 11 & 12 & 23 \\
$\quad$ Mean & 24 & 23 & 24 \\
$\quad$ Range & $16-37$ & $17-36$ & $16-37$ \\
$\begin{array}{l}\text { Sex (M:F) } \\
\text { Duration of exposure (y) } \\
\quad \text { Mean }\end{array}$ & $3: 8$ & $7: 5$ & $10: 13$ \\
$\quad$ Range & 6.63 & 5.6 & 6.2 \\
\hline
\end{tabular}

arate back room where the bleaches were handled there was no air extraction at the point of mixing. Stylists were exposed to the bleaches only after they had been mixed and did not handle them in powder form.

The salon had been open for only three years, but some of its staff had been employed as specialised tinters elsewhere. We have also studied the respiratory response to bleach powder in two asthmatic hairdressers (subjects 24 and 26) not working at this salon, one of whom had a history of asthma precipitated by bleach exposure, as well as in two non-exposed asthmatics with hyperreactive airways and four nonexposed non-asthmatic subjects (table 3 ). All subjects gave informed written consent to this study.

\section{METHODS}

All subjects attended the laboratory while still employed at the salon and still exposed to bleach powder, for the following:

\section{Questionnaire}

There is no standardised validated questionnaire for the diagnosis of asthma. The Medical Research Council questionnaire on chronic bronchitis was used in the survey with additional questions relating to allergic disease of the respiratory tract. Questionnaires were administered by two trained interviewers.

\section{Lung function tests}

Spirometry was performed in triplicate with a Vitalograph dry bellows spirometer and peak flow was measured with a Wright peak flow meter. $\mathrm{FEV}_{1}$ and forced vital capacity (FVC) were considered normal if they were within two standard deviations of predicted normal values. ${ }^{8}$ In subjects with normal lung function bronchial provocation testing with histamine was undertaken by the method described by Chai et al. ${ }^{9}$ Increasing doses of histamine (from $0.25 \mathrm{mg} / \mathrm{ml}$ to 25 $\mathrm{mg} / \mathrm{ml}$ ) were inhaled at five minute intervals from a de Vilbiss 646 nebuliser attached to a Rosenthal-French (Laboratory for Applied Immunology, Baltimore, USA) breath activated dosimeter until the $\mathrm{FEV}_{1}$ had fallen by $20 \%$ of its baseline value or the subject had inhaled the maximum concentration of histamine. The dose of histamine required to produce a $20 \%$ fall in $\mathrm{FEV}_{1}$ was designated the provocation dose, $\mathrm{PD}_{20} \mathrm{FEV}_{1}$, and expressed in cumulative breath units (CBU). In our laboratory asthmatic individuals have been found to react to doses of $100 \mathrm{CBU}$ or less and patients with rhinitis alone to doses ranging from 100 to $1000 \mathrm{CBU}$. normal subjects being unreactive. ${ }^{10}$

Table 2 Clinical details of patients studied in the hairdressing salon

\begin{tabular}{|c|c|c|c|c|c|c|c|c|c|c|c|c|}
\hline No & $\begin{array}{l}\text { Age } \\
(y)\end{array}$ & Sex & $\begin{array}{l}\text { Respiratory } \\
\text { symptoms }\end{array}$ & $\begin{array}{l}\text { Nasal } \\
\text { symptoms }\end{array}$ & $\begin{array}{l}\text { Occupational } \\
\text { symptoms }\end{array}$ & $\frac{F E V}{F V C} 1 \%$ & $\begin{array}{l}\text { Histamine } \\
\text { provocation } \\
P D_{20} \\
(C B U)\end{array}$ & Atopy & $\begin{array}{l}\text { Smoking } \\
\text { (pack } \\
\text { years) }\end{array}$ & $\begin{array}{l}\text { Duration of } \\
\text { exposure } \\
\text { (y) }\end{array}$ & $\begin{array}{l}\text { Duration of } \\
\text { symptoms } \\
\text { (URT) } \\
(y)\end{array}$ & $\begin{array}{l}\text { Response to } \\
\text { specific } \\
\text { bronchial } \\
\text { challenge }\end{array}$ \\
\hline $\begin{array}{r}1 \\
2 \\
3 \\
4 \\
5 \\
6 \\
7 \\
8 \\
9 \\
10 \\
11 \\
12 \\
13 \\
14 \\
15 \\
16 \\
17 \\
18 \\
19 \\
20 \\
21 \\
22 \\
23\end{array}$ & $\begin{array}{l}19 \\
22 \\
22 \\
25 \\
21 \\
19 \\
20 \\
21 \\
25 \\
36 \\
31 \\
21 \\
24 \\
22 \\
24 \\
19 \\
16 \\
17 \\
22 \\
23 \\
37 \\
36 \\
17\end{array}$ & $\begin{array}{l}F \\
\mathbf{F} \\
\mathbf{M} \\
\mathbf{F} \\
\mathbf{M} \\
\mathbf{F} \\
\mathbf{F} \\
\mathbf{M} \\
\mathbf{M} \\
\mathbf{F} \\
\mathbf{M} \\
\mathbf{M} \\
\mathbf{M} \\
\mathbf{M} \\
\mathbf{F} \\
\mathbf{M} \\
\mathbf{F} \\
\mathbf{F} \\
\mathbf{F} \\
\mathbf{F} \\
\mathbf{F} \\
\mathbf{M} \\
\mathbf{F}\end{array}$ & $\begin{array}{l}\text { W } \\
0 \\
0 \\
\text { S } \\
W \\
C \\
S \\
0 \\
W \\
S \\
0 \\
0 \\
0 \\
0 \\
W \\
0 \\
0 \\
0 \\
W \\
W \\
C, S \\
C \\
W\end{array}$ & $\begin{array}{l}+ \\
0 \\
+ \\
0 \\
+ \\
0 \\
+ \\
0 \\
0 \\
0 \\
0 \\
0 \\
+ \\
+ \\
+ \\
0 \\
+ \\
0 \\
+ \\
+ \\
0 \\
0 \\
+\end{array}$ & $\begin{array}{l}+ \\
0 \\
+ \\
0 \\
+ \\
0 \\
0 \\
0 \\
0 \\
0 \\
0 \\
0 \\
0 \\
0 \\
+ \\
0 \\
+ \\
0 \\
+ \\
0 \\
+ \\
0 \\
0\end{array}$ & $\begin{array}{l}83 \\
93 \\
85 \\
88 \\
85 \\
96 \\
93 \\
91 \\
92 \\
91 \\
96 \\
88 \\
95 \\
79 \\
88 \\
89 \\
81 \\
90 \\
96 \\
89 \\
92 \\
84 \\
94\end{array}$ & $\begin{aligned} & 10 \\
&> 1000 \\
& 450 \\
&>1000 \\
& 30.5 \\
&>1000 \\
& 200 \\
&>1000 \\
& 7.5 \\
&>1000 \\
&>1000 \\
&>1000 \\
& 500 \\
& 140 \\
& 7.3 \\
&> 1000 \\
& 220 \\
&> 1000 \\
& 20 \\
&> 1000 \\
&> 1000 \\
&> 1000 \\
& 70\end{aligned}$ & $\begin{array}{l}+ \\
+ \\
0 \\
0 \\
+ \\
0 \\
+ \\
+ \\
+ \\
0 \\
+ \\
+ \\
+ \\
0 \\
\overline{0} \\
0 \\
0 \\
0 \\
+ \\
0 \\
0 \\
0 \\
+\end{array}$ & $\begin{array}{l}0.07 \\
0 \\
0 \\
11.78 \\
0 \\
6 \\
2.5 \\
10.3 \\
3.86 \\
16 \\
5.14 \\
0 \\
0 \\
4.1 \\
1.5 \\
0 \\
0 \\
0.86 \\
0 \\
10.5 \\
16.1 \\
14.7 \\
0.86\end{array}$ & $\begin{array}{c}2 \\
5 \\
5 \\
5 \\
3 \\
4 \\
3 \\
3 \\
3 \\
12 \\
16 \\
5 \\
7 \\
3 \\
8 \\
4 \\
0.5 \\
0.5 \\
2.5 \\
5 \\
23 \\
2 \\
0.5\end{array}$ & $\begin{array}{l}0.5 \\
- \\
-2 \\
2.25 \\
6 \\
10 \\
- \\
10 \\
- \\
- \\
- \\
- \\
- \\
1.5 \\
- \\
- \\
-2 \\
2 \\
15 \\
3\end{array}$ & $\begin{array}{l}+ \\
0 \\
\text { ND } \\
0 \\
+ \\
0 \\
0 \\
0 \\
0 \\
\text { ND } \\
\text { ND } \\
\text { ND } \\
\text { ND } \\
\text { ND } \\
+ \\
0 \\
0 \\
0 \\
+ \\
\text { ND } \\
\text { ND } \\
\text { ND } \\
0\end{array}$ \\
\hline
\end{tabular}


respiratory tract; ND-not done. 
Table 3 Clinical details of control subjects

\begin{tabular}{|c|c|c|c|c|c|c|c|c|}
\hline No & Age & Sex & Respiratory symptoms & $\frac{F E V}{F V C} \%$ & $\begin{array}{l}\text { Histamine } \\
\text { provocation } \\
P D_{20} \\
(C B U)\end{array}$ & Atopy & $\begin{array}{l}\text { Smoking } \\
\text { (pack } \\
\text { years) }\end{array}$ & $\begin{array}{l}\text { Response to } \\
\text { specific } \\
\text { bronchial } \\
\text { challenge }\end{array}$ \\
\hline $\begin{array}{l}24 \\
25 \\
26 \\
27 \\
28 \\
29 \\
30 \\
31\end{array}$ & $\begin{array}{l}19 \\
21 \\
27 \\
24 \\
33 \\
23 \\
34 \\
31\end{array}$ & $\begin{array}{l}\mathbf{F} \\
\mathbf{F} \\
\mathbf{F} \\
\mathbf{M} \\
\mathbf{M} \\
\mathbf{F} \\
\mathbf{M} \\
\mathbf{M}\end{array}$ & $\begin{array}{l}\text { Work related asthma } \\
\text { Asthma non-occupational } \\
\text { Asthma non-occupational } \\
\text { Asthma non-occupational } \\
\text { None } \\
\text { None } \\
\text { None } \\
\text { None }\end{array}$ & $\begin{array}{l}72 \\
93 \\
92 \\
86 \\
91 \\
93 \\
89 \\
88\end{array}$ & $\begin{aligned}< & 5 \\
& 12.5 \\
< & 5 \\
& 20 \\
> & 1000 \\
> & 1000 \\
> & 1000 \\
> & 1000\end{aligned}$ & $\begin{array}{l}+ \\
+ \\
0 \\
+ \\
+ \\
0 \\
+ \\
0\end{array}$ & $\begin{array}{l}0 \\
0 \\
5 \\
7.5 \\
10 \\
0 \\
2.5 \\
0\end{array}$ & $\begin{array}{l}+ \\
0 \\
0 \\
0 \\
0 \\
0 \\
0 \\
0\end{array}$ \\
\hline
\end{tabular}

All subjects were provided with mini Wright portable peak flow recorders and diary cards and instructed in their use. They were asked to record peak expiratory flow rates (PEF) at least four times daily for three weeks both at and away from work. Peak flow charts were plotted and examined for patterns of work related asthma according to the criteria of Burge et al. ${ }^{11}$ Variability was calculated for each day by expressing the difference between maximum and minimum recordings for that day as a percentage of the maximum value for the day. Variability of more than $20 \%$ on any day after the first two is usually considered to indicate asthma. ${ }^{12}$

\section{Immunological tests}

Skinprick tests were performed according to the method described by Pepys ${ }^{13}$ with four common inhalant allergens (house dust, house dust mite, grass pollen, and Aspergillus fumigatus-Bencard, Brentford, Middx) and the resulting weals were compared with the site of a negative control. A skin test weal with a diameter at least $2 \mathrm{~mm}$ greater than the control area was regarded as significant.

\section{Specific occupational tests}

Skinprick tests with aqueous solutions of ammonium persulphate (molecular weight 228 daltons: concentrations from $10^{-6}$ to $\left.1 \mathrm{~mol} / \mathrm{l}\right)$ and potassium persulphate (molecular weight 270 daltons: from $10^{-6}$ to $10^{-1} \mathrm{~mol} / \mathrm{l}$ ) were performed in all subjects undergoing specific provocation tests as well as in four male and two female healthy atopic subjects aged 17-33 years. Specific bronchial provocation tests were undertaken according to a standard method. ${ }^{14}$ Subjects were admitted to hospital for the duration of the occupational challenge. Thirty grams of bleach powder were mixed with $50 \mathrm{~g}$ of lactose and tipped from one tray into another $30 \mathrm{~cm}$ away in a challenge chamber with independent air extraction. Subjects were closely monitored during the challenge procedure. All subjects were challenged for 10 minutes unless respiratory symptoms developed before this time, in which case the challenge was terminated. Only two subjects un- derwent challenge for less than 10 minutes-subject 1. was challenged for three minutes and subject 24 for $\overrightarrow{\mathrm{N}}$ five minutes. Changes in pulmonary function were $\mathrm{O}$ followed in all patients by measuring $\mathrm{FEV}_{1}, \mathrm{FVC}$, and PEF at five minute intervals for the first hour and at $\vec{c}$ hourly intervals thereafter. A response was considered positive when $\mathrm{FEV}_{1}$ fell by more than $20 \%$ of its baseline value in the absence of any change in re- 2 sponse to a control challenge of lactose powder alone $\vec{\varphi}$ conducted on a separate day.

In six subjects detailed studies of pulmonary mechanics were undertaken. In addition to $\mathrm{FEV}_{1}, \mathrm{FVC}$, and PEF, recordings of flow-volume loops, airways resistance, lung volumes (measured by the helium rebreathing technique), and single breath carbon mon- $\frac{\circ}{\Phi}$ oxide transfer were made. Flow-volume loops and $\varrho$ airway resistance were recorded at 15 minute intervals $\overrightarrow{\overrightarrow{0}}$ for the first hour, and hourly thereafter. Lung vol- 3 umes and gas transfer were recorded at two hourly intervals. Prechallenge lung function tests were performed twice before each occupational challenge test. Flow-volume loops were recorded by plotting flow at the mouth, recorded with a Fleisch pneumotachograph and Validyne pressure transducer, $\frac{\sigma}{3}$ against lung volumes derived from the plethysmograph. Airways resistance was measured according $\frac{9}{3}$ to the method of Dubois. ${ }^{15}$ Lung volumes and gas transfer were measured with the PK Morgan Respi- 옥 rometer. Control challenges were performed using $\frac{7}{0}$ lactose alone on a separate day according to an identical protocol, and the patient was blind to the nature $N$ of the challenge. In all, 21 subjects underwent bron- $N$ chial challenge: 14 members of the salon, one hair- $\mathcal{N}$ dresser with a history of work related asthma (subject $\omega$ 24), one hairdresser with asthma that was not related to work (subject 25), two non-exposed asthmatic patients (subjects 26 and 27), and four healthy subjects $₫$ (subjects 28-31). Nine members of the staff of the + salon refused to undergo occupational challenge.

The nasal responses to occupational challenge was recorded by the technique of anterior rhinometry with $\stackrel{\rho}{\square}$ the PK Morgan nasal resistance tester-NART (PK@ Morgan, Chatham). ${ }^{16} \mathrm{~A}$ challenge was considered 
positive when a three fold or greater rise in nasal resistance in either nostril was recorded in the absence of change in the control challenge.

\section{Plasma histamine and neutrophil chemotactic activity} Blood was taken before challenge with bleach powder; 5,15 , and 60 minutes after challenge; and two hourly thereafter from subjects $1,5,9,14$, and 25-31. Plasma was separated immediately and stored at $-70^{\circ} \mathrm{C}$ until assayed for histamine with the double isotope radioenzymatic assay, ${ }^{17}$ which in our laboratory has a sensitivity down to $0.5 \mathrm{nmol} / 1$ and intra-assay and interassay coefficients of variation of $7 \%$ and $15 \%$ respectively. Neutrophil chemotactic activity was assayed with a modification of the Boyden technique. ${ }^{18}$ This biological assay has in our laboratory intra-assay and interassay coefficients of variation of $20 \%$ and $40 \%$ respectively. Neutrophil chemotactic activity was characterised by separation by means both of a Sephadex G-200 gel filtration column and of a Superose GB column.

\section{Basophil counts}

About $0.5 \mathrm{ml}$ of whole blood was mixed with toluidine blue (containing $0.5 \mathrm{ml}$ of saponin per $11 \mathrm{ml}$ stain) to disrupt red cells. Cells were counted in a standard haematocytometer.

\section{Statistical methods}

Comparisons were made where appropriate with Fisher's exact test, the $\chi^{2}$ test, or the Mann-Whitney U test. ${ }^{19}$

\section{Results}

\section{RESULTS OF QUESTIONNAIRE}

Seven subjects complained of symptoms consistent with a diagnosis of current asthma (more than one attack of wheezing, cough, or shortness of breath within the last year). Symptoms appeared work related in four - that is, they deteriorated at work during the day and improved at weekends or during holidays. Three with non-work related symptoms had had these before working in the salon. Four other subjects complained of exertional dyspnoea and one of these reported greater dyspnoea during the working day, although she had no work related wheezing. Three others-all cigarette smokers-had a nonproductive morning cough on most days.

Nasal symptoms (attacks of sneezing or a blocked or runny nose) were reported by 10 individuals, in five of whom lower respiratory symptoms were also present. Only four had nasal symptoms that were related to work and improved away from the salon.

All of those who reported work related respiratory symptoms had been exposed to bleach powders for at least six months before the onset of symptoms, and many had been exposed to similar compounds before working in this salon, None, however, had developed symptoms before this employment.

Fifteen subjects were current smokers. Five of the seven with symptoms of asthma were atopic, as were all three of those with morning cough and all four with exertional dyspnoea. Six out of eight non-smokers had no respiratory symptoms. All subjects with respiratory symptoms considered that the bleach powders were the cause of their respiratory complaints.

\section{LUNG FUNCTION}

All subjects had normal $\mathrm{FEV}_{1}, \mathrm{FVC}, \mathrm{PEF}$, and $\mathrm{FEV}_{1} / \mathrm{FVC}$ ratio at the time of testing.

\section{NON-SPECIFIC BRONCHIAL REACTIVITY}

Six subjects reacted to less than $100 \mathrm{CBU}$ of histamine, a level of reactivity consistent with symptomatic asthma. ${ }^{10}$ Five reacted to doses of $100-1000 \mathrm{CBU}$ (usually found in patients with rhinitis) and 12 were unreactive to histamine in the doses used.

\section{ATOPY}

Eleven subjects were atopic (having one or more positive skinprick test responses), 11 were non-atopic, and one had dermatographism. Five out of six of the asthmatic subjects were atopic. Six atopic subjects had no symptoms of allergic respiratory disease.

\section{RELATIONSHIP BETWEEN SYMPTOMS AND}

NON-SPECIFIC BRONCHIAL REACTIVITY

Symptoms of asthma were reported by all six individuals who had abnormally increased bronchial reactivity, though one with normal reactivity gave a history that was consistent with asthma (not work related). Spirometric results were normal in all subjects. Mean FEV $_{1}$ was lower in those who complained of respiratory symptoms, but individuals with and without symptoms could not be distinguished on the basis of spirometric measurements alone.

Respiratory symptoms were significantly associated with increased bronchial reactivity $(p<0.002)$ and smoking $(p<0.05)$. Even though five of the seven asthmatic subjects were atopic, seven of the 16 nonasthmatic subjects were atopic, and there was no significant relationship between respiratory symptoms and atopy.

\section{PEAK FLOW CHARTS}

Peak flow charts were returned by $19(83 \%)$ of the staff but complete recordings were provided only by $12(52 \%)$. Variability of over $20 \%$ on one day or more was found in four subjects, two of whom had symptoms of asthma and bronchial reactivity in the asthmatic range. The third subject with variability of more 
than $20 \%$ had rhinitis but denied respiratory symptoms. The fourth had normal bronchial reactivity and no symptoms of wheezing but did complain of exertional dyspnoea and morning cough. Of the six subjects with symptoms of asthma who returned adequately completed records, four had no days on which variability was greater than $20 \%$. Peak flow charts were examined for the presence of work related patterns of asthma according to the criteria of Burge et al. ${ }^{11}$ Only one subject (No 1) showed a typical work related pattern (fig 1). She also had a positive response to histamine and specific occupational provocation with bleach powder.

\section{SPECIFIC BRONCHIAL PROVOCATION TESTS}

Twenty five bronchial provocation tests with occupational materials were undertaken in 22 subjects. Fourteen members of the salon were challenged with bleach powder and three were also challenged with persulphate salts. In addition, three asthmatic subjects without a history of work related respiratory disease, one asthmatic hairdresser with work related wheezing, and four normal subjects were challenged with bleach powder.

Positive responses to challenge with bleach powder occurred in all four employees of the salon with work related respiratory symptoms who also had histamine bronchial reactivity in the asthmatic range (subjects 1 , $5,15,19)$. Challenge also gave a positive result in the asthmatic hairdresser who worked elsewhere (subject 24). Challenges with bleach powder had negative results in all other subjects, including the asthmatics without a history of work related symptoms (subjects

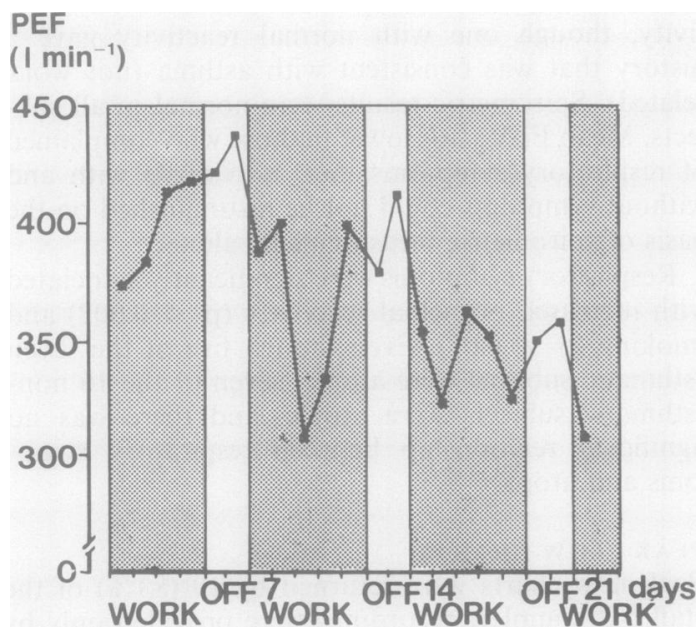

Fig 1 Peak flow rate (PEF) chart of subject 1: mean daily peak flow rates plotted against time, showing work related decline in peak flow rates with weekend improvement. Shaded areas represent time at work.
$9,23,25-27)$. A late asthmatic response occurred in all subjects reacting to bleach powders (fig 2). Typically the fall in $\mathrm{FEV}_{1}$ began two to four hours after challenge and returned to normal within eight hours, although in subject 1 the response continued for 12 hours. No immediate responses were observed. Three individuals who had reacted to bleach powder were also challenged with potassium persulphate powder and identical bronchial responses were observed (fig 2). Positive bronchial responses to bleach powder were found only in tinters.

Detailed studies of pulmonary mechanics were undertaken in three subjects who had a positive response to bronchial challenge with bleach powder (table 4). Although both FEV $_{1}$ and FVC fell significantly in those with a positive response to challenge, lung volumes and gas transfer remained unchanged. No changes were seen in flow rates at $50 \%$ of lung volume $\left(\dot{\mathrm{V}}_{50}\right)$ or specific conductance (sGaw) in the first hour in any of the subjects undergoing bronchial challenge with bleach powder (fig 3).

Percentage changes following bronchial challenge with bleach powder in $\mathrm{FEV}_{1}, \mathrm{FVC}, \mathrm{PEF}, \dot{\mathrm{V}}_{50}$, sGaw, $\mathrm{KCO}$, and TLC for these three subjects, for two subjects with asthma not related to work, and two subjects without asthma are shown in table 4 and figures 3 and 4. Changes in flow rates $\left(\mathrm{FEV}_{1}, \mathrm{PEF}, \dot{\mathrm{V}}_{50}\right.$, and sGaw) were significantly greater in the three subjects with work related asthma than in the four controls, but there were no significant differences in lung volumes or gas transfer.

\section{RESULTS OF NASAL CHALLENGE}

The nasal response to occupational challenge was recorded in 13 individuals. Positive responses were

FEV,

(I)

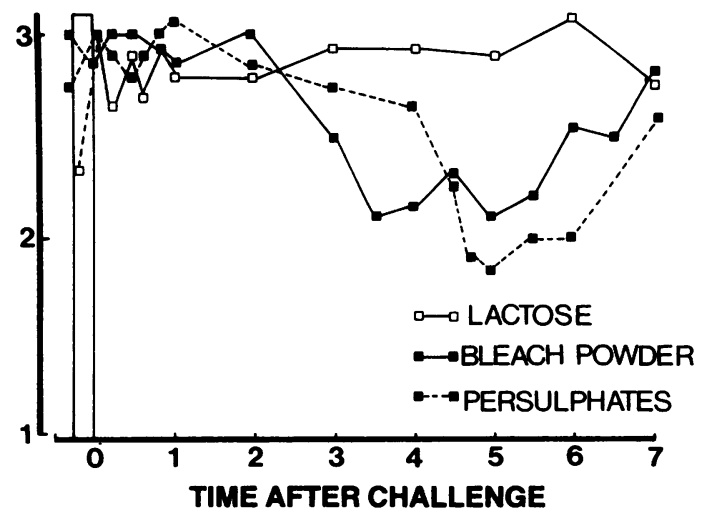

Fig 2 Bronchial response to specific bronchial provocation tests with bleach powder and persulphate salts in subject 15 . 
Table 4 Changes in lung function after bronchial provocation with bleach powder (maximum percentage change from baseline after provocation test with bleach or lactose)

\begin{tabular}{|c|c|c|c|c|c|c|c|c|}
\hline & & $\triangle F E V_{1} \%$ & $\triangle F V C \%$ & $\triangle P E F \%$ & $\Delta V_{50} \%$ & $\Delta s G a w \%$ & $\triangle \mathrm{KCO} \%$ & $\triangle T L C \%$ \\
\hline $\begin{array}{l}\text { Work related } \\
\text { asthma }(n=3) \\
\text { Non-work related } \\
\text { asthma }(n=2) \\
\text { Normal controls } \\
(n=2)\end{array}$ & $\begin{array}{l}\text { Bleach } \\
\text { Lactose } \\
\text { Bleach } \\
\text { Lactose } \\
\text { Bleach } \\
\text { Lactose }\end{array}$ & $\begin{array}{r}-42.5 \\
-10.2 \\
-7.8 \\
-4.0 \\
-4.4 \\
-5.8\end{array}$ & $\begin{array}{l}-31.0 \\
-9.7 \\
-7.6 \\
-7.5 \\
-4.2 \\
-5.4\end{array}$ & $\begin{array}{l}-35.4 \\
-1.0 \\
-6.5 \\
-5.1 \\
-5.3 \\
-3.1\end{array}$ & $\begin{array}{c}-48.63 \\
-8.75 \\
+1.80 \\
-10.20 \\
-5.5 \\
-3.5\end{array}$ & $\begin{array}{r}-55.3 \\
-12.0 \\
-9.1 \\
-34.0 \\
-15.8 \\
-26.5\end{array}$ & $\begin{array}{c}-8.0 \\
+13.0 \\
-19.5 \\
-36.0 \\
-2.75 \\
0\end{array}$ & $\begin{array}{r}-12.75 \\
-4.00 \\
-12.60 \\
-3.60 \\
+3.30 \\
-11.50\end{array}$ \\
\hline
\end{tabular}

$\triangle$-change; $\mathrm{FEV}_{1}$-forced expiratory volume in one second; FVC - forced vital capacity; $\hat{\mathrm{V}}_{50}-$ flow rate at $50 \%$ of lung volume; sGawspecific conductance; $\mathrm{KCO}$ - transfer coefficient; TLC - total lung capacity.

found in all subjects who had positive responses to bronchial challenge, the peak response occurring at about the same time as the maximum bronchial response (fig 5). Responses in those with no history of work related rhinitis were negative.

\section{RESULTS OF SKIN TESTS WITH PERSULPHATE}

\section{SALTS}

Skin tests with persulphate salts were performed on 14 members of the salon, six non-exposed atopic subjects and two exposed hairdressers without a history of
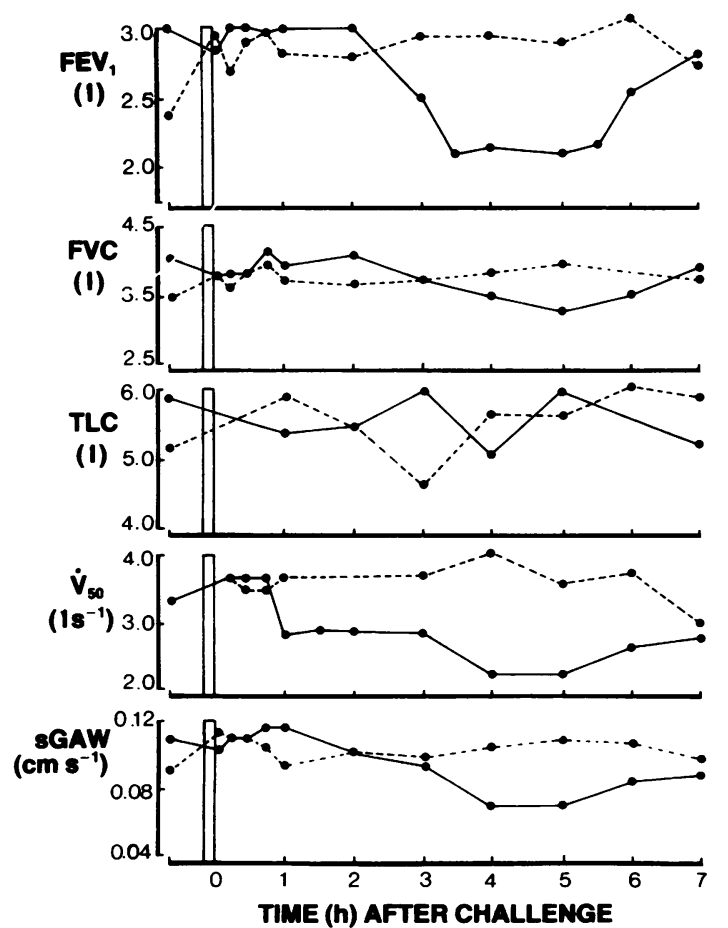

Fig 3 Pattern of respiratory reaction after provocation with bleach powder and placebo in subject 5 , who had work related asthma. $\bullet-$ bleach powder; $\bullet--\bullet$ placebo. work related asthma. There was only one positive response in subject 1 who developed a $3 \mathrm{~mm}$ weal and flare to a molar solution of ammonium persulphate and a $10^{-1} \mathrm{~mol} / \mathrm{l}$ solution of potassium persulphate.

\section{MEDIATOR RELEASE AFTER CHALLENGE}

Plasma histamine concentration did not rise significantly in subjects with or without work related asthma after challenge with bleach powder. In those with positive responses to bleach powder there were significant rises in serum levels of neutrophil chemo-



TIME AFTER CHALLENGE

Fig 4 Pattern of respiratory response after bronchial provocation with bleach powder in normal subject 16. 


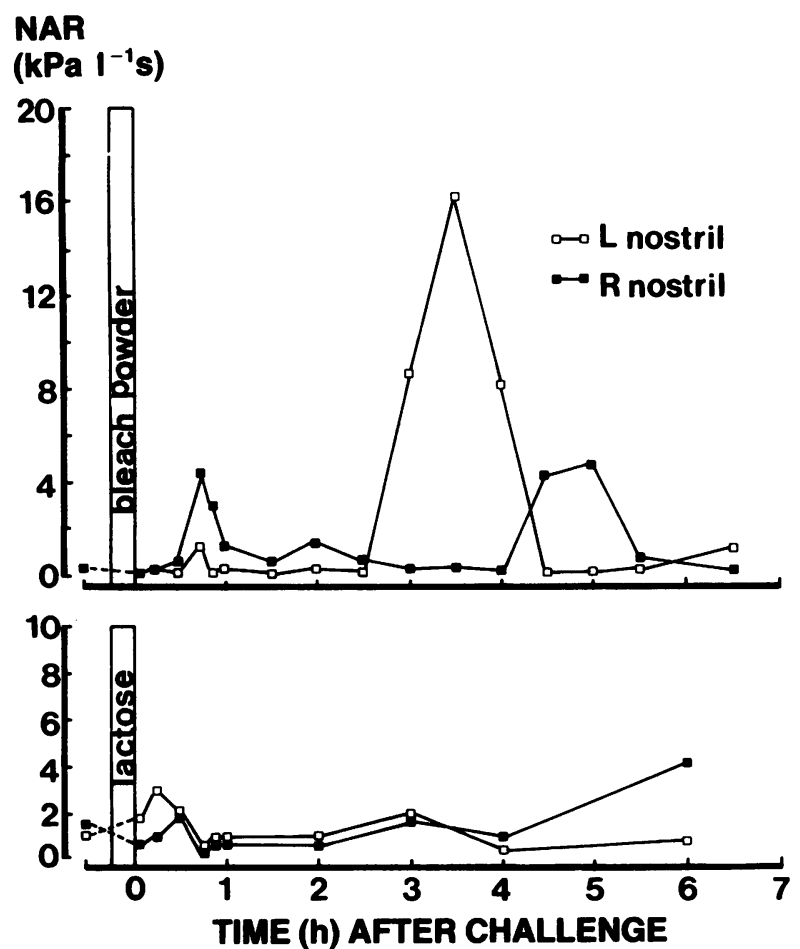

Fig 5 Nasal response to provocation with bleach powder in subject 19, who had work related asthma and rhinitis. $N A R$ - nasal airway resistance.

tactic activity after challenge, and the serum levels three to five hours after challenge were significantly higher $(\mathrm{p}<0.05)$ than in asthmatic and nonasthmatic subjects with negative responses to provocation with bleach powder (fig 6). Sephedex G200 column separation of this neutrophil chemotactic activity showed that it consisted of two peaks, one of molecular weight $>74 \times 10^{5}$ daltons $<2 \times 10^{6}$ daltons and a low molecular weight fraction of $<200$ $\times 10^{3}$ daltons. Superose GB column separation showed three distinct high molecular weight peaks-1 $\times 10^{6}, 6 \times 10^{5}$, and $4 \times 10^{5}$ daltons-as well as a low molecular weight fraction of $<60 \times 10^{3}$ daltons. The neutrophil chemotactic activity detected in these subjects has the same characteristics as that found in our laboratory in the serum of allergic asthmatic subjects after bronchial provocation with allergen. Basophil counts rose in all subjects after provocation with bleach powder, but the differences in basophil counts between those with a positive response to challenge and those with a negative response were not significant.

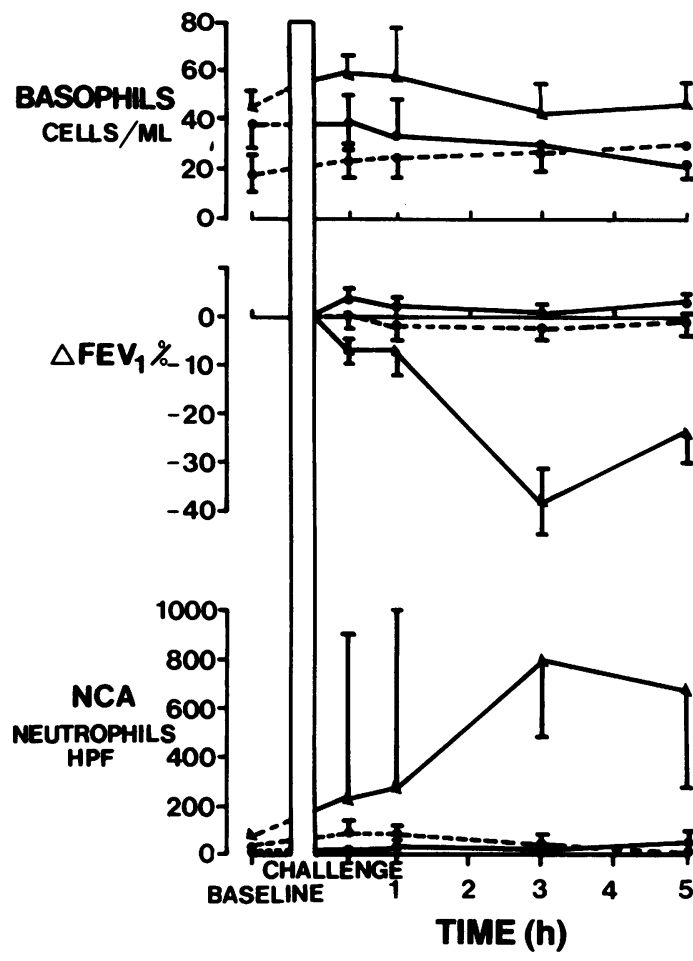

Fig 6 Changes in basophils, neutrophil chemotactic activity, and $F E V_{1}$ in three subjects with work related asthma (_- ), three subjects with asthma not related to

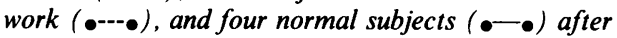
bronchial provocation with bleach powder.

\section{Discussion}

Four out of 23 staff employed at a hairdressing salon developed occupational asthma due to inhalation of

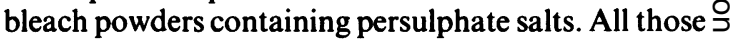
who had developed work related respiratory disease $?$ had been heavily exposed to bleaches containing persulphates in powder form for at least six months be- $N$ fore the onset of symptoms, although there were in the salon several individuals who despite equivalent or greater exposure to bleaches had not developed respi- $\omega$ ratory disease. All those with work related asthma? were tinters, and directly concerned in mixing bleacho powders; none of the stylists had developed work re- $\mathbb{D}$ lated asthma. Although we could not quantify ex- -+ posure to bleach powders in this salon, this $\frac{0}{-}$ observation suggests that those who had the greatest $\frac{\text { + }}{\mathbb{D}}$ exposure were most likely to develop work related $\stackrel{\square}{\oplus}$ asthma.

The results of this small scale study show the value 
of testing for non-specific bronchial reactivity in the assessment of occupational lung disease. Asthma may be difficult to identify solely on the basis of the history, and some objective assessment is required. In this group spirometric tests performed on a single occasion were of no value in distinguishing affected from unaffected individuals. Peak flow records have been used to diagnose asthma in the work environment but were disappointing in this study, identifying only one individual with work related asthma.

There were several reasons why peak flow recordings were insensitive in this study for the diagnosis of asthma. One of the subjects continued to take inhaled sodium cromoglycate throughout the period of investigation, and peak flow recordings were made only four times a day. The poor completion rate of peak flow records in this study, only about half of which were adequate, implies that more frequent recordings, as suggested by Burge et al, ${ }^{11}$ would have been difficult for the busy staff of this salon to complete. It is difficult to explain why two individuals without symptoms of asthma produced peak flow charts showing variability of more than $20 \%$ on at least one day. This degree of variability certainly suggests asthma, but neither had symptoms of this disease or bronchial reactivity in or near the asthmatic range. Possibly bleach powders were having a non-specific irritant effect on the airways of some individuals, as grain dust has been shown to do. ${ }^{20}$ Alternatively, errors may occur in the performance of ambulatory peak flow meters, which are largely operated unsupervised.

For all these reasons tests of non-specific bronchial reactivity may be of greater value than ambulatory peak flow records in screening for asthma in an occupational group. Histamine bronchial provocation tests were completed in all individuals surveyed and low $\mathrm{PD}_{20}$ values were obtained only in patients with symptoms of asthma.

Bronchial provocation testing with bleach powder confirmed that the response to these agents was specific and not simply an irritant response in individuals with hyperreactive airways, since subjects without a history of work related asthma but with increased airways reactivity did not develop airways constriction on inhalation of bleach powder. Detailed studies of pulmonary mechanics after challenge indicated that the response was asthmatic in nature: flow rates declined whereas lung volumes and gas transfer were unchanged. The airway responses to inhaled bleach powders have rarely been studied but in the few cases adequately described responses were immediate, unlike the asthmatic reactions seen in our study, which were non-immediate. The nasal response to challenge was similar to the bronchial response, the peak rises in nasal airway resistance coinciding with the maximum fall in $\mathrm{FEV}_{1}$ (fig 5). Rises in nasal airway resistance after challenge with lactose were seen in five subjects, but all occurred within the first few minutes after provocation and presumably resulted from an irritant response to lactose. The rise in nasal airway resistance in those who responded to bleach powder was not seen in the two nostrils simultaneously, because changes in the opposite nostril were suppressed by the nasal reflex, as shown by Hasegawa and Kern. ${ }^{21}$ Recordings of total nasal resistance would have failed to indicate any change. These results show the value of anterior rhinometry in recording the response to nasal challenge.

The mechanism of asthma due to bleach powders containing persulphate salts is unknown. As with other types of occupational asthma, certain features suggest an allergic pathogenesis. Only a proportion of those exposed were affected, and there was a latent period of several months between first exposure and the onset of symptoms. Skinprick testing with persulphate salts, however, gave a positive result in subject 1 only, in whom a 1 and $10^{-1} \mathrm{~mol} / \mathrm{l}$ solution of ammonium persulphate and a $10^{-1} \mathrm{~mol} / \mathrm{l}$ solution of potassium persulphate were required to produce a $3 \mathrm{~mm}$ weal. Previous reports have described positive responses to skin tests with persulphate salts, in general at much lower concentrations, in some but not all patients with occupational asthma due to these agents. Specific IgE has not been found in the serum of any patients with respiratory disease due to persulphate salts.

A rise in serum neutrophil chemotactic activity has been found in various disorders in which allergic mechanisms are important - for example, allergen induced asthma ${ }^{22}$ and cold urticaria. ${ }^{23}$ While the exact origin of neutrophil chemotactic activity in man remains to be determined, many consider that in vivo neutrophil chemotactic activity is released from mast cells. The significant rise in serum levels of neutrophil chemotactic activity paralleling airflow obstruction suggests that mast cells may play a part in the pathogenesis of the late asthmatic reaction following inhalation of persulphate salts. The mechanism by which mast cell activation may occur in asthma due to persulphates remains unknown. Studies on animal mast cell preparations have shown that persulphate salts can release histamine directly, ${ }^{24}$ but on this basis it remains necessary to explain why only some individuals are affected and not others.

Although a study of a single salon cannot be used to estimate the prevalence of work related respiratory disease among hairdressers in general, it is clear that under some circumstances a substantial proportion of the work force may be affected by bleach powders containing persulphate salts. Those exposed to these bleaches should be advised to avoid inhalation of the 
dust. This could be achieved by the provision of extractor hoods at the site where the bleaches are mixed.

We acknowledge with gratitude the assistance of the technical staff of the Academic Unit of Respiratory Medicine, particularly Caroline Gould for help with provocation testing and Wendy Smart for plasma histamine assays. We thank the staff and management of the hairdressing salon for their patient cooperation, and Kim Clarke and Laura Roberts for typing the manuscript. ADB was supported by a grant from the Chest, Heart, and Stroke Association and RS had financial support from the Medical Research Council.

\section{References}

1 Zuskin E, Boujuys A. Acute airway responses to hairspray preparations. $N$ Engl J Med 1974;290:660-3.

2 Gaultier M, Gervais P, Mellerio F. Deux causes d'asthme professionel chez les coiffeurs: persulfate et soie. Arch Mal Prof 1966;27:809-13.

3 Fisher AA, Dooms-Goosens A. Persulfate hair bleach reactions: cutaneous and respiratory manifestations. Arch Dermatol 1976;112:1407-9.

4 Pepys J, Hutchcroft BJ, Breslin ABX. Asthma due to inhaled chemical agents - persulphate salts and henna in hairdressers. Clin Allergy 1976;6:399-404.

5 Baur X, Fruhmann G, Liebe VV. Occupational asthma and dermatitis after exposure to dusts of persulfate salts in two industrial workers. Respiration 1979;38:144-50.

6 Starr JC, Yunginger J, Brasher GW. Immediate type I asthmatic response to henna following occupational exposure in hairdressers. Ann Allergy 1982;48:98-9.

7 Gelfand HH. Respiratory allergy due to chemical compounds encountered in the rubber, lacquer, shellac and beauty culture industries. $J$ Allergy 1963;34:374-81.

8 Cotes JE. Lung function: principles and application in medicine. 4th ed. Oxford: Blackwell Scientific Publications, 1979.

9 Chai H, Farr RS, Froehlich LA, et al. Standardisation of bronchial inhalation challenge procedures. J Allergy Clin Immunol 1975;56:323-7.

10 Davies RJ, Morgan DJR, Blainey AD. Bronchial reactivity: its assessment and clinical value. In: Morley $\mathrm{J}$, ed.
Bronchial reactivity. London: Academic press, 1982.

11 Burge PS, O'Brien IM, Harries MG. Peak flow records in the diagnosis of occupational asthma due to colophony. Thorax 1979;34:308-16.

12 Venables KM, Burge PS, Davison AG, Newman Taylor AJ. Peak flow records in surveys; reproducibility of observers' reports. Thorax 1984;39:828-32.

13 Pepys J. Atopy. In: Gell PGH, Coombes RRA, eds. Clinical aspects of immunology. Oxford: Blackwell Scientific Publications, 1975.

14 Pepys J, Pickering CAC, Hughes EC. Asthma due to inhaled chemical agents - complex salts of platinum. Clin Allergy 1972;2:391-6.

15 Dubois AB, Botelho SY, Comroe JH jun. A new method for measuring airway resistance in man using a body plethysmograph. J Clin Invest 1956;35:327-35.

16 Britton MG, Empey DW, John GC, McDonnel KA, Hughes DTD. Histamine challenge and anterior nasal rhinometry: their use in the assessment of pseudoephedrine and triprolidine as nasal decongestants in subjects with hay fever. Br J Clin Pharmacol 1978;6:51-8.

17 Brown MJ, Ind PW, Causon R, Lee TH. A novel double blind isotope technique for the enzymatic assay of plasma histamine: application to estimation of mast cell activation assessed by antigen challenge in asthmatics. $J$ Allergy Clin Immunol 1982;69:20-4.

18 Cundell DR, Moodley I, Davies RJ. Properties of a high molecular weight neutrophil chemotactic factor derived from mast cells: evidence for chemokinetic rather than chemotactic activity. Agents Actions 1984;14:484-7.

19 Siegel S. Non parametric statistics for the behavioural sciences. New York: McGraw Hill, 1956.

20 Do Pico GA, Flaherty D, Bhansali P, Chavaje N. Grain fever syndrome induced by inhalation of airborne grain dust. J Allergy Clin Immunol 1982;69:435-43.

21 Hasegawa M, Kern EB. Variations in nasal resistance in man: a rhinomonometric study of the nasal cycle in 50 human subjects. Rhinology 1978;16:19-29.

22 Kay AB, Lee TH. Neutrophil chemotactic factor of anaphylaxis. J Allergy Clin Immunol 1982;70:317-20.

23 Wasserman SI, Soter NA, Center DM, Austen KF. Cold urticaria. Recognition and characterisation of a neutrophil chemotactic factor which appears in serum during experimental cold challenge. J Clin Invest 1977;60: 189-96.

24 Parsons JF, Goodwin BJF, Safford RJ. Studies on the action of histamine release by persulphates. Food Cosmet Toxicol 1979;17:129-35. 